\author{
Filip Rakoczy-Nazimek* \\ ORCID: 0000-0003-4634-9112 \\ Uniwersytet Wrocławski
}

https://doi.org/10.19195/1733-5779.31.2

\title{
Populizm orzeczniczy w stosowaniu prawa a prawo jednostki do bezstronnego sądu
}

\section{JEL Classification: K38, K41, K30}

Słowa kluczowe: populizm, stosowanie prawa, Trybunał Konstytucyjny, bezstronność

Keywords: populism, application of law, Constitutional Tribunal, impartiality

\begin{abstract}
Abstrakt: W tekście zajmuję się analizą zjawiska populizmu w dziedzinie stosowania prawa. Przede wszystkim rekonstruuję pojęcie populizmu na podstawie dorobku nauk politologicznych i prawnych. Następnie, przy wykorzystaniu dorobku współczesnej polskiej teorii i filozofii prawa, rekonstruuję możliwe przestrzenie argumentacji populistycznej w stosowaniu prawa. Na przykładach orzeczeń Trybunału Konstytucyjnego wskazuję na konkretne strategie argumentacyjne, oparte na schematach populistycznych, po to by na końcu wskazać na narzędzia, umożliwiające heurystykę i polemikę z taką argumentacją.
\end{abstract}

\section{Judicial populism in the application of the law and the right to an impartial court}

\begin{abstract}
In my paper I analyze the phenomenon of populism present in the field of law application. First, I reconstruct the concept of populism on the basis of the achievements of political science and law. Then, using the achievements of modern Polish theory and philosophy of law, I reconstruct the possible spaces for populist argumentation in the sphere of law application. Using the examples of decisions made by the Constitutional Tribunal, I point to specific argumentative strategies based on populist schemes, in order to finally point to tools enabling heuristics and polemics with such argumentation.
\end{abstract}

* Opiekun naukowy (Scientific Tutor) — dr Michał Paździora 


\section{Wstęp}

W niniejszym tekście rozważać będę wpływ zjawiska populizmu na sferę stosowania prawa. Jest to zjawisko znane także w innych naukach społecznych. Mimo odmiennych definicji tam występujących w tekście postaram się zsyntetyzować to pojęcie na potrzeby omawianego zagadnienia i zestawić je z dotychczasowym dorobkiem nauk prawnych, zwłaszcza prawa karnego. Następnie opiszę wpływ tego zjawiska, konkretnie na sferę stosowania prawa w postaci rekonstrukcji populistycznych strategii argumentacyjnych, przy wykorzystaniu przykładów, w szczególności orzecznictwa Trybunału Konstytucyjnego. Ostatecznie przedstawię metody dekonstrukcji tej argumentacji i polemiki z populistami w sferze stosowania prawa.

\section{Populizm w naukach prawnych i politologicznych}

W naukach prawnych pojęcie populizmu nie ma znacznego zaplecza teoretycznego. Dotychczas występowało ono głównie w publikacjach z zakresu prawa karnego, w odmianie „populizmu penalnego". Autorzy tych publikacji, poza poruszaniem problemów związanych bezpośrednio z prawem karnym, wskazywali także na ogólną problematykę zdefiniowania populizmu, odwołując się zarówno do słowników, jak i prac z zakresu socjologii i politologii. Mimo tych trudności $\mathrm{w}$ literaturze budowano definicję populizmu penalnego w publikacjach o charakterze dogmatyczno-prawnym. Odwoływano się w tym zakresie do literatury anglosaskiej, w której pojawiło się pojęcie „,populistycznej punitywności”, rozumianej jako „zespół społecznych przekonań charakteryzujący się punitywnym nastawieniem do przestępczości i mniejszym niż kiedyś współczuciem dla jej sprawców, w odniesieniu do którego politycy czują się zobligowani dać odpowiedź"2. W. Zalewski, odwołując się do przedstawionego opisu, ostatecznie skonstruował definicję populizmu penalnego jako „zespołu społecznych przekonań, a także działań politycznych i legislacyjnych podejmowanych z programowym ograniczaniem roli ekspertów, współkształtowanego przez media, charakteryzującego się surowym nastawieniem dla przestępczości i brakiem współczucia dla jej sprawców"3. Definicja Zalewskiego jest o tyle istotna, że nie traktuje populizmu wyłącznie jako zjawiska społecznego, ale także wskazuje, że jest on formą strategii politycznej. Autor ten zwrócił także uwagę na genezę postaw populistycznych. Wskazał on,

${ }^{1}$ Por. Populizm penalny i jego przejawy w Polsce, red. Z. Sienkiewicz, R. Kokot, Wrocław 2009; Penalny populizm. Perspektywa polityczna i spoleczna, red. J. Czapska, M. Szafrańska, D. Wójcik, Kraków 2016.

2 A. Bottoms, The philosophy and politics of Punishment and Sentencing [w:] In The Politics of Sentencing Reforms, red. Ch. Clarkson, R. Morgan, Oxford 1995, s. 23 n.

3 W. Zalewski, Populizm penalny - próba zdefiniowania zjawiska, [w:] Populizm penalny i jego przejawy..., s. 32 . 
że jedną z głównych osi krytyki przyjętego w USA i Skandynawii systemu „dobroczynnego karania” przyjętego w drugiej połowie XX wieku było to, że nie został on uzgodniony ze społeczeństwem. Dostrzega on w swojej pracy, w ślad za I. Loaderem, że ostrzem tej krytyki było wykorzystanie społecznych emocji wobec przestępstwa i kary oraz zarzut, że głęboko antydemokratycznym jest utrzymywanie przestępstwa z dala od życia publicznego, pod bezpieczną kontrolą ekspertów ${ }^{4}$. Wskazuje on, że politykę penalną państwa ustalano odgórnie, z inicjatywy państwowej, co również w perspektywie miało przyczynić się do powstania i umocnienia postaw populistycznych w stosunku do przyjętej filozofii karania ${ }^{5}$.

Można zwrócić uwagę na to, że wskazany mechanizm socjologiczny jest tożsamy z tym, jaki był rekonstruowany także w filozofii politycznej, między innymi przez Ch. Mouffe, która wskazywała, że:

Teoretycy, którzy pragną uwolnić politykę od namiętności i sprowadzają politykę demokratyczną do rozumu, umiarkowania i konsensusu, ukazują swoje niezrozumienie dynamiki polityczności. Ignorują to, że polityka demokratyczna potrzebuje realnego punktu oparcia w ludzkich pragnieniach i fantazjach, i że zamiast przeciwstawiać interesy uczuciom, a rozum namiętnościom, powinna oferować formy identyfikacji sprzyjające praktyce demokratycznej ${ }^{6}$.

Gdy brakuje takiej konfiguracji, namiętności nie mogą znaleźć demokratycznego ujścia, a agoniczna dynamika pluralizmu ulega stłumieniu. Pojawia się niebezpieczeństwo zastąpienia demokratycznej konfrontacji przez zderzenie esencjonalistycznych form identyfikacji czy też nienegocjowalnych wartości moralnych ${ }^{7}$.

$\mathrm{Na}$ dalsze polityczne aspekty populizmu penalnego wskazywał także T. Kaczmarek, pisząc, że ,ppolitycy programowo deklarując, że ich populistyczne tezy nie są głoszone »na rzecz społeczeństwa«, ale »ze społeczeństwem« i w pełni odpowiadają społecznym oczekiwaniom - akurat w tych przypadkach działają dokładnie przeciwko przeważającej opinii społecznej”. Kaczmarek wskazywał w tym zakresie liczne badania empiryczne, świadczące o tym, że choć Polacy zapytani o politykę karną domagają się zaostrzenia kar, to już zapytani o indywidualne, konkretne przypadki przestępców w przeważającej większości wskazują na kary mieszczące się $\mathrm{w}$ dotychczasowym katalogu i zagrożeniu określonym w już istniejących przepisach ${ }^{8}$. Autor ten, za J. Czapską i S. Waltosiem, wskazywał także, że w debatach publicznych o przestępczości i karaniu ważniejsze od naukowych analiz przestępczości stają się „fakty, o których wszyscy wiemy”. Taka „publiczna wiedza” ma pierwszeństwo przed statystyką przestępczości i jej

4 Ibidem, s. 18.

5 Ibidem, s. 19.

6 Ch. Mouffe, Polityczność. Przewodnik krytyki politycznej, Warszawa 2008, s. 43-44.

7 Ibidem, s. 45.

8 T. Kaczmarek, Racjonalny ustawodawca wobec opinii społecznej a populizm penalny, [w:] Populizm penalny i jego przejawy..., s. 41-50. 
naukowymi opracowaniami ${ }^{9}$. Taki mechanizm argumentacyjny populistów zauważa także A. Prowotorow-Pryka ${ }^{10}$, która odwołuje się do koncepcji populizmu P. Taggarta, opartej na pojęciu „rdzenna kraina”. Koncepcja ta polega na tworzeniu wyobrażenia rdzennej krainy zamieszkiwanej przez rekonstruowany przez populistów $l^{1} \mathrm{~d}^{11}$. Ta analiza pozostaje $\mathrm{z}$ kolei zgodna $\mathrm{z}$ tezami formułowanymi przez Jana-Wernera Mullera odnośnie do tego, że cechą charakterystyczną populistów jest nieempiryczne moralne rekonstruowanie ,ludu”, który oni reprezentują ${ }^{12}$. Lud taki powstaje jako esencjonalistyczne wyobrażenie, wytworzone na podstawie stereotypowych lub pożądanych cech danego kraju; dlatego też politycy populiści będą często mówić o „prawdziwych” obywatelach danego kraju.

Ta rekonstrukcja tworzy nam w miarę spójny obraz postrzegania populizmu przez prawników. Wskazuje się na jego antyeksperckość, opieranie się na zrekonstruowanej moralnie woli większości, odwoływanie się raczej do emocji niż racjonalizmu. Obraz ten dodatkowo pozostaje zgodny z przywoływanymi tezami socjologów i politologów. Populizm w tym znaczeniu jest postrzegany przez prawników jako czynnik zewnętrzny, wpływający na ustawodawstwo, pozostający w konflikcie $\mathrm{z}$ racjonalnością ustawodawcy, która $\mathrm{z}$ kolei ma pochodzić od badań i analiz prowadzonych przez środowiska eksperckie. Czynnik ten nie jest racjonalny; opiera się na emocjach i namiętnościach ludzkich. Tak rozumiany populizm dotyczy jednak wyłącznie sfery tworzenia prawa, w której ustawodawca staje się podatny na populistyczną argumentację.

Na gruncie nauk prawnych zasadniczo nie rozważa się natomiast, czy postawy populistyczne mogą przejawiać się także w dziedzinie stosowania prawa. Wydaje się, że sfera ta jest poza podejrzeniem, głównie ze względu na to, że pozostaje domeną silnej władzy środowisk eksperckich — sędziów, prokuratorów, urzędników czy profesjonalnych pełnomocników. Pozornie populizm, jako antyelitarystyczny, nie powinien znajdować tam oparcia. Z drugiej strony, jeżeli przypomnimy sobie, że jest to nie tylko zjawisko społeczne, ale także strategia polityczna, argument ten bardzo traci na sile. Za poszukiwaniem populizmu również w tej sferze przemawiać zdają się tezy formułowane zarówno przez J.W. Mullera ${ }^{13}$, jak i T. Kaczmarka $^{14}$. Sprowadzają się one do tego, że populizm u władzy ma zdolność do reprodukcji w tym sensie, że potrafi wpływać na opinię publiczną i będzie dążył do ukształtowania faktycznego ludu lub narodu na wzór tego wyobrażonego przez populistów. Dotyczy to także polityki penalnej, która ukształtowana i promowa-

9 Ibidem, s. 39.

10 Por. A. Prowotorow-Pryka, Penalny populizm jako zespół społecznych przekonań, [w:] Penalny populizm...

11 P. Taggart, Populizm, lud, rdzenna kraina, [w:] Populizm, red. O. Wysocka, Warszawa 2010, s. 80 .

12 J.W. Muller, Co to jest populizm?, Warszawa 2017, s. 47-56.

13 Ibidem, s. 78.

14 T. Kaczmarek, op. cit., s. 49-50. 
na przez ustawodawcę wpływać będzie na postawy i poglądy opinii publicznej. W związku z tym zjawisko to w perspektywie będzie miało także wpływ na prawników jako część społeczeństwa i wskazanej opinii publicznej. To oznacza, że z czasem postawy populistyczne będą mogły zacząć przejawiać się także w sferze sądowego stosowania prawa.

\section{Potencjał populistyczny w stosowaniu prawa}

Jeżeli rozumiemy populizm, poza zespołem przekonań, także jako określoną strategię budowania kapitału politycznego, będziemy musieli zauważyć, że jest on określoną formą strategii argumentacyjnej. W demokratycznym społeczeństwie każda strategia działań politycznych, dla swojego uzasadnienia, opierać się musi na chociażby rudymentarnej strategii argumentacyjnej. Populiści rekonstruują moralnie ,prawdziwy naród” lub ,prawdziwy lud”, będący dla nich źródłem wyłącznej i niepodważalnej legitymizacji władzy. Każdy, kto krytykuje legitymizację populistów, zostanie określony jako ich wróg. Wszelkie badania empiryczne (w tym na przykład referenda) mają zatem przede wszystkim walor perswazyjny, znacznie rzadziej poznawczy - mają utwierdzać ich legitymizację, a nie ustalać faktyczną ,wolę” ludu ${ }^{15}$, ponieważ ta została wcześniej już przez populistów ustalona. W związku z tym wydaje się, że retoryka populistyczna się będzie opierać na rozumowaniu ,zdroworozsądkowym”, częstym mieszaniu sfery powinności (wyobrażonego ,ludu”) ze sferą faktów (faktyczną strukturą społeczną) oraz częstym odwoływaniem do pojęć definiowalnych jedynie w uwikłaniu, należących do słownika finalnego populistów. To oznacza, że wyłącznymi dysponentami tego pojęcia stają się sami populiści — każdy, kto się z nimi nie zgadza, będzie albo wrogiem, albo co najwyżej ,,pożytecznym głupcem”, ponieważ występuje przeciw prawdziwemu ludowi, działając na rzecz skorumpowanych elit. Należy zatem rozważyć, czy mimo reprodukcji postaw populistycznych i możliwego wykorzystania takich schematów argumentacyjnych przez sądy, możemy je w ogóle nazywać ,populistycznymi” w dotychczasowym rozumieniu, albowiem jest to pojęcie ściśle powiązane z rzekomą „reprezentacją” ludu. Sądy, jako organy z założenia niezawisłe, nikogo nie reprezentują i nie wywodzą swojego mandatu z wyborów powszechnych. Z drugiej strony, częstym zarzutem formułowanym w Polsce jest, że sądy służą własnym interesom (,interesom kasty”) bądź interesom elit, a nie społeczeństwu jako całości. Politycy, którzy zdaniem Mullera ${ }^{16}$ wpisują się w nurt populistycznej polityki, otwarcie mówią o przywracaniu sądów narodowi. Zastanówmy się zatem, w jaki sposób takie sądy, opierające swoje orzeczenia na strategiach populistycznych, będą lub powinny orzekać. Jak wynika z przytoczonych wcześniej publikacji dotyczących populizmu penalnego, na pewno elementem

\footnotetext{
15 J.W. Muller, op. cit., s. 53-54.

16 Ibidem, s. 12.
} 
takiego orzekania będzie zaostrzenie kar w prawie karnym. To, z jednej strony, dokonało się na etapie tworzenia prawa, w drodze nowelizacji kodeksu karnego $^{17}$. Z drugiej strony wyobrazić sobie możemy także postawy sędziów, którzy w ramach swobody pozostawionej im przez ustawodawcę będą wymierzać kary surowsze w ramach wykonywania swojej władzy dyskrecjonalnej i reinterpretacji zasad wymiaru kary. Tym, co będzie dla nas istotne z perspektywy niniejszej pracy, jest jednak sposób uzasadniania takich wyroków, nie tylko karnych.

Muller wprost nazywa populizm szczególnym rodzajem moralizującej wyobraźni politycznej. Niewątpliwie prawnicy, poza posługiwaniem się rozmaitymi strategiami argumentacyjnymi, posługują się także wyobraźnią. Wiele miejsca wyobraźni jako jednemu z czterech kluczowych elementów myślenia prawniczego (oprócz intuicji, języka i racjonalności) poświęcił Bartosz Brożek w swoim Umyśle prawniczym. Wyobraźnia, w rozumieniu tego autora, umożliwia prawnikom prowadzenie symulacji mentalnych. Wskazuje on na dwie, w mojej ocenie podstawowe z perspektywy niniejszego tekstu, funkcje tych symulacji: heurystyczną i hermeneutyczną. Wydaje się, że w zakresie realizacji tych dwóch funkcji prawniczych symulacji myślowych rozumowania te są szczególnie podatne na ich populistyczne wypaczenie, ponieważ opierają się właśnie na symulacjach myślowych, korzystających z prawniczej wyobraźni i często wymagają odniesienia się do systemów zewnętrznych wobec prawa. Na rolę takich symulacji zwracano uwagę w literaturze już wcześniej, wskazując między innymi na aksjologiczne uwikłanie postępowania dowodowego w pracach L. Leszczyńskiego ${ }^{18}$.

Funkcja heurystyczna w pracach B. Brożka sprowadza się zasadniczo do interpretacji stanu faktycznego i lepszego zrozumienia istoty sprawy, poprzez utożsamienie się przez sąd ze stronami sporu, ich sytuacją i motywacjami, a także wyobrażanie sobie analogicznych sytuacji, dla których istnieją już rozstrzygnięcia ${ }^{19}$. W ramach wskazania przykładu dla takiej operacji myślowej autor ten w swojej pracy odwołuje się do sprawy Van Gend en $\operatorname{Loos}^{20}$. Operacje myślowe, takie jak analogia lub eksperyment myślowy, dla swojego skutecznego wykorzystania, wymagają ich zakorzenienia w ludzkiej wyobraźni. W przeciwnym wypadku staną się „teoretycznymi potworkami”, opartymi na zasadniczo nieskończonej liczbie

17 Dokonało się to między innymi za pomocą ustawy z dnia 23 marca 2017 roku o zmianie ustawy - Kodeks karny, ustawy o postępowaniu w sprawach nieletnich oraz ustawy — Kodeks postępowania karnego.

${ }^{18}$ L. Leszczyński, Zagadnienia teorii stosowania prawa. Doktryna i tezy orzecznictwa, Kraków 2001, s. 69-70.

19 B. Brożek, Umyst prawniczy, Kraków 2018, s. 102 n.

20 Ibidem, s.103-104. Sprawa dotyczyła naliczenia podwyższonej opłaty celnej od importu produktu, ze względu na jego inną, zmienioną w ostatnim czasie, klasyfikację prawną, pomimo traktatowych gwarancji powstrzymania się przez państwa członkowskie od wprowadzania nowych i podwyższania dotychczasowych ceł. Sprawa była rozpoznawana przez Europejski Trybunał Sprawiedliwości (obecnie Trybunał Sprawiedliwości Unii Europejskiej). 
zmiennych, ponieważ prawnik stosujący te rozumowania nie będzie miał żadnych narzędzi do intuicyjnego wychwycenia osi lub istoty sporu, nie mówiąc już o zdolności do ich odtworzenia ${ }^{21}$. Wartościowym przykładem tego rodzaju rozumowania jest argumentacja przedstawiona w uzasadnieniu wyroku Trybunału Konstytucyjnego z dnia 7 lipca 2015 roku, K 47/12, w którym Trybunał, orzekając wprost, podkreślał, że zgodność z Konstytucją danej regulacji wymaga wyważenia interesów poszczególnych grup społecznych, których dotyka regulacja ${ }^{22}$.

W orzeczeniu Trybunał nie tylko ustalił pozycję obu stron sporu, ale także, co istotniejsze, rozważył fizyczne i ekonomiczne możliwości podmiotów objętych kwestionowaną regulacją do realizacji obowiązków, wynikających z aktów prawa unijnego. Przeniesienie populistycznej argumentacji na ten grunt będzie oznaczało, że sędzia będzie usiłował zrekonstruować „,społeczne poczucie sprawiedliwości”, na którego podstawie będzie orzekał, ewentualnie będzie usiłował odtworzyć cechy charakterystyczne „narodu”, budując wzorce osobowe, wykorzystywane w prawie, takie jak należyta staranność, niedbalstwo i lekkomyślność, dobra lub zła wiara. W tym kontekście możemy wyobrazić sobie interpretację, która stwierdza na przykład, że zasada sprawiedliwości społecznej wymaga przyznania a priori pierwszeństwa dobru wspólnemu przed indywidualnym interesem osób niepełnosprawnych. Takie rozumowanie nosiłoby cechy populizmu, albowiem wyklucza osoby niepełnosprawne z ogólnego rozumienia wspólnoty społecznej i politycznej, rekonstruując tę wspólnotę moralnie, a także w sposób arbitralny regulowałoby hierarchię wartości chronionych prawnie, ze względu na przyjętą wizję społeczeństwa.

Funkcja hermenteutyczna dotyczy z kolei interpretacji (rozumienia) abstrakcyjnego tekstu prawnego w celu zastosowania go do konkretnego stanu faktycznego. Brożek zwraca tu uwagę na takie narzędzia myślowe, jak egzemplifikacja, parafraza i osadzenie przepisu w szerszym kontekście, które są wykorzystywane przez prawników do określenia, czy dana norma obejmuje ustalone zachowanie człowieka ${ }^{23}$. Możemy sobie wyobrazić, że na etapie wykładni prawa taki sędzia może kłaść znaczny nacisk na wykładnię systemową z mocnym nawiązaniem do rekonstruowanej przez siebie aksjologii, lub funkcjonalną poprzez rekonstrukcję celów danego przepisu $\mathrm{w}$ perspektywie realizacji woli suwerena. Doskonałym zobrazowaniem takiego sposobu myślenia jest treść art. 4 ust. 1 Konstytucji PRL, w którym wprost wskazano, że „prawa Polskiej Rzeczypospolitej Ludowej są wyrazem interesów i woli ludu pracującego", gdyby rozumieć go jako regułę egzegezy tekstu prawnego. Przepis ten był populistyczny w tym sensie, że nakazywał pośrednio interpretację wszystkich przepisów prawa przez pryzmat ,woli ludu”, albowiem to, co jest z nim

21 Ibidem, s. 111-112.

22 https://ipo.trybunal.gov.pl/ipo/view/sprawa.xhtml?\&pokaz=dokumenty\&sygnatura=K\%20 47/12 (dostęp: 25.03.2020).

23 Ibidem, s. 116 n. 
sprzeczne, nie może być prawem. Jednocześnie oczywiste jest, że wola ludu w tamtym okresie była przez PZPR redefiniowana w zależności od potrzeb, a nie odtwarzana w realizacji procedur demokratycznych. Drugim przykładem takiej strategii argumentacyjnej jest słynne już stwierdzenie, że ,za czynienie dobra nie wsadzamy", stanowiące fragment rozmowy wiceministra sprawiedliwości z osobą, która miała zajmować się poszukiwaniem i tworzeniem informacji dyskredytujących określonych sędziów ${ }^{24}$. Stwierdzenie to można odczytać jako swoisty kontratyp pozaustawowy, zgodnie $\mathrm{z}$ którym działanie w interesie populistycznie zrekonstruowanego „narodu” lub „ludu” może modyfikować odpowiedzialność karną danego podmiotu. Oczywiście, istnieje wiele konkurencyjnych koncepcji wykładni, z których żadna nie ma pozycji usankcjonowanej w jakikolwiek sposób. Z perspektywy realizmu prawniczego można wręcz stwierdzić, że dyrektywy wykładni nie mają znaczenia, albowiem orzekający może ich w ogóle nie stosować, przy dochodzeniu do sentencji, uzasadniając swoją decyzję wyłącznie a posteriori. Ze względu jednak na to, że dyrektywy wykładni są, choćby fasadową, częścią naszej kultury prawniczej, będę się do nich odnosił w dalszych rozważaniach.

W mojej ocenie, przykładem takiego populistycznego rozumowania przy interpretacji przepisów, jest wyrok Trybunału Konstytucyjnego z dnia 26 czerwca 2019 roku, który zapadł pod sygnaturą akt: K 16/17, w tak zwanej sprawie drukarza. Przedmiotem kontroli był art. 138 k.w., penalizujący nieuzasadnioną odmowę sprzedaży towaru lub świadczenia usług lub nieuzasadnione zawyżenie ceny. W niniejszym tekście pominę ewentualne wątpliwości dotyczące prawidłowości obsady i funkcjonowania Trybunału w ostatnich latach, skupiając się wyłącznie na uzasadnieniu orzeczenia. Moim zadaniem jest rekonstrukcja argumentacji leżącej u podstaw wydawanych aktów stosowania prawa; w związku z czym taka analiza mieściłaby się poza zakresem przedmiotowym niniejszej pracy i nie wydaje się czytelnikowi potrzebna do analizy omawianego zjawiska. W uzasadnieniu wyroku Trybunał przedstawił następującą argumentację:

Zdaniem Trybunału, trudno uznać, by penalizacja odmowy świadczenia usługi bez uzasadnionej przyczyny zaspokajała społeczne poczucie sprawiedliwości. Rozwiązanie to nie spełnia też celu ogólnoprewencyjnego. Ma to związek przede wszystkim z niską świadomością społeczną co do charakteru kwestionowanej regulacji, jaki się jej obecnie przypisuje. Jak wynika ze stanowiska Rzecznika Praw Obywatelskich, za naruszenie art. 138 k.w. sankcje są niewysokie, a w praktyce na sprawców tego typu wykroczeń nakłada się niewielkie grzywny albo odstępuje od wymierzenia kary (zob. s. 12-13 stanowiska RPO i podane tam przykłady z orzecznictwa).

\section{$[\ldots]$}

Analizując adekwatność art. 138 k.w. do celów, które są mu obecnie przypisane, Trybunał Konstytucyjny stwierdził, że sankcja wynikająca z art. 138 k.w. i praktyka jej stosowania nie potwierdzają tezy, że rozwiązanie to oddziałuje na sprawcę wykroczenia w taki sposób, że nie popełni on

${ }^{24}$ Por. między innymi https://wiadomosci.onet.pl/tylko-w-onecie/sledztwo-onetu-farma-trolli-w-ministerstwie-sprawiedliwosci-czyli-za-czynienie-dobra/j6hwp7f (dostęp: 29.02.2020). 
w przyszłości danego czynu. Karanie za nieuzasadnioną odmowę świadczenia usługi, o której mowa w art. 138 k.w., nie jest też środkiem, który skutecznie chroni konsumentów. Kwestionowana norma nie kompensuje w dostateczny sposób naruszenia związanego z dyskryminacją. By naprawić uszczerbek w dobrach osobistych osoby, która doznała dyskryminacji, konieczne jest bowiem uruchomienie innych środków prawnych (zwłaszcza dotyczących odszkodowania i zadośćuczynienia).

\section{$[\ldots]$}

Zdaniem Trybunału, art. 138 k.w. nie jest przydatny ani do ochrony interesów ekonomicznych konsumentów, ani do ochrony niematerialnych interesów konsumentów, ani wreszcie do ochrony przed działaniami antydyskryminacyjnymi. Jeśli jednym z podstawowych interesów konsumenta jest to, by usługa, o którą się zwraca była zrealizowana, a z art. 138 k.w. nie wynika obowiązek określonego działania dla zobowiązanego do świadczenia, to ukaranie za odmowę świadczenia usług umyślnie bez uzasadnionej przyczyny nie ochroni interesów konsumenta.

Art. 138 k.w. nie realizuje też celu antydyskryminacyjnego. Analiza praktyki stosowania skarżonej normy potwierdza, że w sprawach dotyczących art. 138 albo wymierzane kary są niskie, albo sąd odstępuje od ich wymierzenia. Trudno zatem uznać, że skarżona norma ma walor prewencyjny czy wychowawczy. Nie realizuje ona także funkcji represyjnej ${ }^{25}$.

Analizując powyższe fragmenty, należy zwrócić uwagę na założenia i entymematy leżące u podstaw orzeczenia Trybunału. Sam Trybunał w uzasadnieniu wskazał, że „najpierw zajął się zarzutem najdalej idącym, a więc adekwatnością rozwiązania, które polegało na penalizacji odmowy świadczenia usługi bez uzasadnionej przyczyny przez osobę zajmującą się zawodowo świadczeniem usług, do zakładanych celów legislacyjnych"26. Autorzy uzasadnienia zwracają uwagę na to, że zaskarżany przepis nie gwarantuje nabywcy prawa do skutecznej realizacji zawartej umowy lub wymuszenia na dostawcy jej zawarcia, a jedynie penalizuje tego rodzaju zachowanie. Dodatkowo Trybunał uznaje, że rozwiązanie nie zaspokaja ani społecznego poczucia sprawiedliwości, ani celu ogólnoprewencyjnego. Uzasadnieniem tego jest niska świadomość społeczna co do charakteru regulacji, jak również charakter sankcji nakładanych na sprawców. Ostatecznie w uzasadnieniu wskazano, że art. 138 k.w. nie tylko nie realizuje swojego celu, ale także wydaje się zbędny ze względu na inne regulacje antydyskryminacyjne oraz zakres regulacji art. 24 k.c. W tym kontekście wyrok został słusznie skrytykowany przez sędziego Leona Kieresa, który w zdaniu odrębnym wskazał 27 , że Trybunał dokonał przeniesienia problemu dyskryminacji ze sfery prywatnej do sfery publicznej, poprzez uznanie, że dyskryminacja jest jedynie problemem istniejącym pomiędzy jednostkami w płaszczyźnie horyzontalnej, a nie powinna być traktowana jako problem państwowy, adresowany także z perspektywy wertykalnej. Zaznaczył on także, że Trybunał nie dokonał właściwie żadnej analizy

25 https://ipo.trybunal.gov.pl/ipo/view/sprawa.xhtml?\&pokaz=dokumenty\&sygnatura=K\%20 16/17 (dostęp: 26.03.2020).

26 Ibidem.

27 Por. zdanie odrębne sędziego L. Kieresa, https://ipo.trybunal.gov.pl/ipo/view/sprawa.xhtml ?\&pokaz=dokumenty\&sygnatura $=$ K\%2016/17\#zdanieodrebne_18339_1 (dostęp: 26.03.2020). 
stosowania kwestionowanego przepisu, pomijając całkowicie konkretne sprawy, przy których znajdował zastosowanie, a które pozwalały zrekonstruować, jakim grupom społecznym faktycznie służy ta regulacja.

Przede wszystkim podzielam zarzut sędziego Kieresa o wyłączeniu problemu dyskryminacji ze sfery publicznej, wbrew treści art. 32 ust. 2 Konstytucji, który zabrania wszelkiej dyskryminacji w życiu politycznym, społecznym i gospodarczym. Tym samym Trybunał, posiłkując się przy okazji odniesieniami do „społecznego poczucia sprawiedliwości”, tworzy własną wizję społeczeństwa, w której dyskryminacja nie jest problemem, który należy poruszać publicznie. Zwracając uwagę na treść art. 24 k.c., faktycznie spycha on to zagadnienie do sfery regulacji cywilnoprawnych pomiędzy jednostkami. To jednocześnie oznacza, że ze względu na przyjęte populistyczne założenia w zasadzie dochodzi do „odpolitycznienia" problemu dyskryminacji, który w ten sposób zostaje wykluczony $z$ toczącej się gry demokratycznej. Konsekwencją takiego założenia jest także konkluzja Trybunału o zbędności art. 138 k.w., ponieważ jeżeli dyskryminacja nie jest problemem społecznym ani publicznym, to państwo nie ma interesu w jego ściganiu. Jednocześnie Trybunał zwraca uwagę, że jeżeli na podstawie tej regulacji zapadają wyłącznie niewielkie kary grzywny lub wręcz odstępuje się od wymierzenia kary, to nie jest on warty zachowania. Takie rozumowanie z kolei kwalifikować można jako opisany na początku niniejszego tekstu populizm penalny, przejawiający się w dążeniu do zwiększenia surowości reakcji karnej. Ostatecznie należy zwrócić uwagę na odwrócenie argumentu ze społecznej świadomości odnośnie regulacji z art. 138 k.w. Celem ustawodawcy i organów władzy publicznej jest zwykle zwiększanie świadomości odnośnie do obowiązujących regulacji i ich wagi. W przedmiotowej sprawie orzekający uznali, że jeżeli świadomość obowiązywania przedmiotowego przepisu jest nikła, to nie jest on wart utrzymania w porządku prawnym, albowiem i tak nie będzie przestrzegany. Tym samym Trybunał niejako wpisał się w twierdzenia Tomasza Kaczmarka, które wskazałem wcześniej - populiści w swoich deklaracjach nie głoszą tez na „rzecz społeczeństwa”, lecz „ze społeczeństwem”. W ten sposób Trybunał, zamiast wskazać na potrzebę upowszechnienia wiedzy na temat przyczyn i sposobu obowiązywania art. 138 k.w., odwraca tę sytuację — skoro określony przepis nie jest uznawany lub przestrzegany przez społeczeństwo, to nie powinien być utrzymywany przez ustawodawcę. Ostatecznie w sentencji uznano art. 138 k.w., w zaskarżanej części, za niezgodny z art. 2 Konstytucji, ze względu na to, że nie spełnia on ogólnego wymogu proporcjonalności. Przywołane uzasadnienie orzeczenia może zostać uznane za populistyczne, albowiem Trybunał swoje wnioski budował, opierając się na niewyrażonych wprost przekonaniach odnośnie do tego, jakie problemy są społecznie istotne i jakie są zagadnieniami publicznymi, leżącymi w sferze zainteresowań państwa, a jakie są problemami wyłącznie pomiędzy jednostkami. Trybunał zbudował także określoną wizję społeczeństwa, które nie uznaje okre- 
ślonych przepisów prawa i nie będzie ich łamać tylko w sytuacji zagrożenia surowszymi karami. W kontraście do tego uzasadnienia można przywołać nie tylko zdanie odrębne sędziego Kieresa, ale także zdanie odrębne Wojciecha Sycha ${ }^{28}$. W swoim tekście wskazuje on, że wolność sumienia może być uzasadnioną przyczyną odmowy świadczenia usług, podkreślając jednocześnie, że dyskryminacja wciąż jest problemem publicznym i społecznym. Innymi słowy ten orzekający nie usiłuje rekonstruować na nowo wizji społeczeństwa, zwracając jednak uwagę na jego różnorodność i skłaniając się jednocześnie ku ochronie interesów określonych grup społecznych. Tym samym wchodzi on częściowo w dyskurs ,polityczności” Ch. Mouffe, proponując wyrok interpretacyjny, odrzucający określone rozumienie jako sprzeczne z prawem krajowym i międzynarodowym, bez odwoływania się do woli ustawodawcy lub społecznej świadomości obowiązywania normy.

\section{Jak populistycznie stosować prawo?}

Wydaje się zatem, że istnieje — niestety — przestrzeń do wykorzystania strategii populistycznych także na etapie sądowego stosowania prawa. Jest to zagadnienie o tyle istotne, że w sytuacji ścisłej kontroli dyscyplinarnej nad sędziami lub kontroli nad obsadą sądów władza populistyczna może usiłować wymuszać na nich stosowanie tych strategii argumentacyjnych. Wcześniej wskazywałem, że szczególnie podatnym na populistyczną argumentację jest stosowanie heurystycznych i hermeneutycznych symulacji mentalnych jako opierających się na prawniczej wyobraźni. Pozostaje nam zatem, przy wykorzystaniu wcześniej przywołanych przykładów, wskazać, jakie części procesu stosowania prawa pozostają podatne na argumenty populistyczne. Możemy przyjąć, że zasadniczo całe stosowanie prawa opiera się na heurezie i hermeneutyce, albowiem są one narzędziami poznania obu sfer działania prawników — sfery faktyczności i obowiązywania. $\mathrm{Z}$ tego względu zagadnienie to zachęca do analizy pod kątem podmiotowym, aniżeli przedmiotowym. Argumentacja prawnicza opiera się jednak raczej na uzasadnianiu i analizie określonych twierdzeń, a także na tak przedstawionej polemice z nimi; o wiele rzadziej interesuje nas to, kto je wypowiada, o ile spełnia podstawowe kryteria instytucjonalne, na przykład jest sędzią lub obrońcą. Z tego względu, analizując populizm w stosowaniu prawa, powinniśmy raczej skupić się na analizie, demaskowaniu i odpieraniu argumentacji populistycznej, aniżeli ,etykietowaniu” poszczególnych aktorów procesu jako ,populistów”. Z perspektywy formalnej zasada bezstronności sądu nie będzie naruszona, ale materialnie rzecz biorąc, populizm wyklucza, także w stosowaniu prawa, określone grupy społeczne, niepasujące do obrazu rekonstruowanego społeczeństwa, czym materialnie narusza zasadę bezstronności.

28 https://ipo.trybunal.gov.pl/ipo/view/sprawa.xhtml?\&pokaz=dokumenty\&sygnatura=K\%20 16/17\#zdanieodrebne_18339_1 (dostęp: 26.03.2020). 
Dotychczas doktryna widziała szczególne niebezpieczeństwo arbitralności orzekających w koncepcji ideologii swobodnej decyzji stosowania prawa ${ }^{29}$. Ta obawa pozostaje częściowo aktualna także w perspektywie pojawiania się populistycznych argumentacji na etapie stosowania prawa. Pole dyskrecjonalnej władzy sędziowskiej wciąż może zostać wykorzystane do ich użycia. Wydaje się jednak, że populizm w tym zakresie sięga dalej, niejako w poprzek systemu prawa, albowiem w pewnych sytuacjach umożliwia obchodzenie nawet konkretnych przepisów w sposób analogiczny ustawie zasadniczej PRL. Z podobną sytuacją mieliśmy do czynienia podczas lektury wyroku TK w sprawie drukarza — Trybunał, zamiast rozszerzać rozumienie art. 138 k.w. w sposób umożliwiający orzekającym sądom jego szerokie stosowanie i ideologicznie zakotwiczoną wykładnię, dokonał zabiegu odwrotnego. W orzeczeniu zasadniczo nie skupiono się na analizie klauzul generalnych ani odsyłających (na przykład „uzasadnionej przyczyny”), które dają orzekającym możliwie szeroką swobodę orzekania ${ }^{30}$, a Trybunałowi wydanie orzeczenia interpretacyjnego, tak jak oczekiwał W. Sych. Ze względu na główne założenia populistów, przywoływane na początku niniejszego tekstu, będą oni postrzegać siebie lub swoją opcję polityczną jako wyłącznych reprezentantów „ludu” lub „narodu”, w związku z czym, zdaje się, że będą dążyli do utworzenia linii orzeczniczej, wykorzystującej co prawda przyznany im luz decyzyjny, jednakże w celu tworzenia jedynej poprawnej interpretacji tekstu prawnego, zgodnej ze zrekonstruowaną przez nich moralnie wizją suwerena. Częściowo zależeć to będzie oczywiście od sytuacji politycznej w kraju i pozycji orzekającego przy wykorzystaniu strategii populistycznych w stosunku do faktycznego ustawodawcy. Przypomnieć należy, że populizm, jak słusznie wskazywał Muller, jest mocno związany z reprezentacją rekonstruowanego moralnie suwerena. To oznacza silne wykorzystanie wykładni celowościowej jako odwołującej się do zamierzeń i celów ustawodawcy. Jednocześnie, ze względu na abstrakcyjność postaci racjonalnego ustawodawcy we współczesnej doktrynie prawniczej, mamy do czynienia z pustym tronem, którego nie może zapełnić żaden realny prawodawca. Tron ten niewątpliwie będzie obsadzony suwerenem w rozumieniu populistycznym, który jest tak nieuchwytny i abstrakcyjny, że można go umieścić w tej roli.

Drugą metodą będzie wykładnia systemowa w ujęciu aksjologicznym, która dotychczas zajmowała miejsce drugorzędne wobec wykładni a rubrica ${ }^{31}$. Cały system prawa, jako pochodzący od wyobrażonego populistycznie suwerena, cechować się będzie spójnym systemem wartości, odtworzonym niezależnie od faktycznych przekonań społecznych, wedle którego interpretowane będą akty prawne. Aksjologia ta będzie rekonstruowana ponownie przy wykorzystaniu

29 Zob. W. Gromski, Ideologia swobodnej decyzji stosowania prawa, [w:] Wprowadzenie do nauk prawnych. Leksykon tematyczny, red. A. Bator, Warszawa 2008, s. 275.

${ }^{30}$ L. Leszczyński, Stosowanie generalnych klauzul odsyłających, Kraków 2001, s. 129.

31 Por. L. Leszczyński, Zagadnienia teorii stosowania prawa..., s. 129 n. 
wytworzonych przez populistów zasad, zwyczajów i „fundamentów cywilizacji”. Przy wykorzystaniu tych dwóch metod wykładni populiści w dalszym ciągu mogą dążyć do zawężania możliwej wykładni aktów prawnych i odbierania orzekającym luzu decyzyjnego w stosowaniu prawa. Należy tu zwrócić uwagę na działanie TK w sprawie drukarza, który zamiast analizować klauzule generalne objęte art. 31 ust. 3 Konstytucji, uznał, że zaskarżana regulacja jest niezgodna już z art. 2 Konstytucji jako całkowicie sprzeczna z ogólną ideą proporcjonalności, wynikającą z zasady demokratycznego państwa prawnego. Innymi słowy tak bardzo zawężono rozumienie aksjologii i zasad ogólnych ustawy zasadniczej, że kwestionowany akt prawny mógł zostać uchylony jeszcze bez przeprowadzania formalnego testu proporcjonalności, jako sprzeczny z samą istotą zasad wywodzonych z art. 2 Konstytucji.

\section{Polemika z populistami}

Trudno polemizować z twierdzeniem, że każdy sędzia wychodzi z jakichś założeń odnośnie do funkcjonowania i struktury społeczeństwa, nierzadko musi nawet te założenia wykorzystywać, stosując klauzule generalne (zasady słuszności, zasady zwykle przyjęte w stosunkach danego rodzaju itp.). Dlaczego zatem skupiać się na populizmie jako jednym z takich zespołów przekonań? Jednym z kluczowych zarzutów formułowanych przez populistów jest twierdzenie, że w rzeczywistości każdy realizuje czyjeś interesy lub urzeczywistnia swoje poglądy — nie ma neutralnej postawy, a każdy, kto twierdzi, że ją prezentuje, jest oszustem.

Argumentem za walką z populistycznym orzecznictwem, w rozumieniu pojęcia tworzonego w literaturze przedmiotu, jest, że działalność ta bardzo mocno zawęża postrzeganie i rozumienie społeczeństwa z perspektywy prawa. To oznacza, że coraz mniej postaw i działań społecznych będzie zrozumiałych lub uznawanych przez prawników za dopuszczalne. Pamiętając, że nasze społeczeństwo i w konsekwencji prawo zaczyna przypominać bazar idei, na którym wszystkie są dostępne i bardziej lub mniej równoprawne ${ }^{32}$, można jednak polemizować z populistycznymi uzasadnieniami, nawet gdy spełniają one formalne kryteria uznania ich za prawidłowe. Będzie to szczególnie istotne w przypadku utworzenia się w przyszłości całych linii orzeczniczych, legitymizujących populistyczną argumentację. Wydaje się, że dziedziną szczególnie podatną na takie działanie jest sfera praw człowieka, w której ze względu na ogólność aktów prawnych i deklaracji programowych istnieje możliwość znacznego zawężenia rozumienia tych praw, na przykład prawa do wolności wypowiedzi, prawa do organizowania pokojowych zgromadzeń (problem zgromadzeń cyklicznych, realnie blokujących pozostałe) lub nawet prawa do życia.

32 A. Kozak, Granice prawniczej władzy dyskrecjonalnej, Wrocław 2002, s. 133. 
Kluczem lub kryterium takiej kontroli wydaje się analiza, czy orzekający nie rekonstruuje moralnie, chociażby w charakterze entymematu, pojęcia „,naród”, „społeczeństwo” lub „lud” w sposób wykluczający z niego określone grupy społeczne, w tym te reprezentowane przez strony danego sporu. Takie działanie narusza zasadę bezstronności sądu, choć raczej jedynie w sensie materialnym, a nie formalnym. W związku z tym w miejscu, w którym dogmatyka traci swoją przydatność, powinniśmy sięgnąć do innych narzędzi. Takimi — w mojej ocenie mogą być dwie niezależne od siebie koncepcje orzekania i odczytywania orzeczeń sądowych. Pierwszą z nich jest stosowanie prawa jako urzeczywistnianie świata tekstu prawnego, zaproponowane przez M. Matczaka ${ }^{33}$. Jak sam autor przyznaje, główną tezą jego pracy jest stwierdzenie, że

rozumienie tekstu [prawnego — F.R.] nie może przebiegać inaczej niż przez wytworzenie w świadomości interpretatora reprezentacji umysłowej, która jest obrazem rzeczywistości podobnej do doświadczonej już wcześniej przez interpretatora rzeczywistości świata realnego ${ }^{34}$.

Podejście Matczaka jest częściowo zbliżone do koncepcji symulacji mentalnych Brożka, do której odwoływałem się wcześniej. Jednocześnie zdejmuje ono W znacznej mierze z procesu stosowania prawa ciężar jego normatywności na rzecz sfery faktów, poprzez porównywanie świata rzeczywistego i możliwego, który wynika z tekstu prawnego. Mimo że autor stara się zdjąć ciężar normatywności z tak opisanego procesu stosowania prawa, pozostawia w swojej koncepcji pewne elementy, które raczej są charakterystyczne dla wyidealizowanego, zupełnego systemu prawa aniżeli świata rzeczywistego. Wskazuje on na przykład na założenie o racjonalności i niesprzeczności świata dekodowanego z treści aktów prawnych $^{35}$. Innym istotnym założeniem tej koncepcji jest teza o tym, że źródłem obowiązku realizacji świata postulowanego jest intencja suwerena, która ma jednak charakter lokucyjny, a nie ilokucyjny — dotyczy bowiem ogólnego posłuchu wobec tekstu prawnego aniżeli jego konkretnego semantycznego znaczenia ${ }^{36}$. Matczak dostrzega także rolę prawników w odtwarzaniu tego świata możliwego, wskazując na konieczność uzupełniania tekstu prawnego o dalsze informacje o tym świecie ${ }^{37}$, a funkcję filtra pełni umysł prawniczy. Autor ten dostrzega zagrożenie zarzutów o subiektywizm i elityzm pozycji prawników, ale zbywa to ryzyko jako niewielkie, powołując się na wspólne wykształcenie prawników we wspólnocie komunikacyjnej oraz racjonalność i podział pracy w społeczeństwie ${ }^{38}$. Mimo tych problemów koncepcja M. Matczaka staje się dla nas istotnym narzę-

33 Zob. M. Matczak, Imperium tekstu. Prawo jako postulowanie i urzeczywistniania świata możliwego, Warszawa 2019, s. 315 n.

34 Ibidem, s. 201.

35 Ibidem, s. 170, 222-224.

36 Ibidem, s. 172.

37 Ibidem, s. 167-169.

38 Ibidem, s. 378-387. 
dziem diagnostycznym odnośnie do argumentacji populistycznej. Teoria ta, jeżeli zostanie potraktowana przez nas wyłącznie jako deskryptywna, dobrze współgra z populistycznym postrzeganiem świata. Populiści, orzekając, będą powoływać się na wyidealizowany lud i poprzez realizację jego woli i interesów będą dążyć do realizacji świata możliwego, poprzez „odzyskiwanie rzeczywistości” (co obrazują hasła, takie jak „make America great again”). W związku z tym ujęcie Matczaka pozwala na demaskowanie argumentacji populistycznej przez przedstawienie świata rzeczywistego oraz postulowanego i wskazanie, na jakich przesłankach, a także w jaki sposób te światy są budowane. Podobną metodę zastosował sędzia L. Kieres w swoim zdaniu odrębnym do wyroku zapadłego w sprawie drukarza. Odwołując się do treści uzasadnienia, wskazał, że rzeczywistość postulowana przez większość składu orzeczniczego jest skupiona na przedsiębiorcach z jednej strony i konsumentach z drugiej. Tymczasem elementem rzeczywistości zastanej są także osoby niepełnosprawne, homoseksualiści oraz rodzice — trzeba ich wszystkich także uwzględnić w wizji świata postulowanego.

W swojej koncepcji M. Matczak zdaje się także kreować świat postulowany jako utopijny, a przynajmniej pożądany społecznie, co oznacza, że w tym ujęciu prawnicy zasadniczo pomagają realizować ustawodawcy ten zamiar. Należy jednak rozważyć, czy koncepcja ta będzie użyteczna, jeżeli sędziowie lub orzekający będą musieli stanąć w kontrze do populistycznego ustawodawcy. Nie piszę tu oczywiście o sytuacji całkowitego nieposłuszeństwa wobec prawa, lecz takiej, w której pojawiająca się legislacja będzie stała w konflikcie z ratyfikowanymi umowami międzynarodowymi lub Konstytucją jako aktami wyższego rzędu. Matczak pozostawia nas tu z dwiema sugestiami: wzmianką o minimum moralnym Fullera ${ }^{39}$ oraz rozważaniami odnośnie do roli hartowskiej reguły uznania w praktyce prawniczej ${ }^{40}$. Te elementy — w mojej opinii — wydają się jednak niewystarczające, albowiem, jak wskazywałem, obecna reguła uznania, opierająca się na regule pochodzenia aktu prawnego, nie pozwala na walkę z argumentacją populistyczną w orzecznictwie. Z tego względu koncepcja M. Matczaka wymaga uzupełnienia o drugie ujęcie, tym bardziej pochodzące zdecydowanie bardziej ze sfery filozofii aniżeli jurysprudencji. Ujęcie to prezentowałem już w jednym ze swoich wcześniejszych tekstów ${ }^{41}$, w którym nawiązałem do jednego z esejów R. Rorty'ego, mówiącym, że:

Dewey-Romantyk byłby wprost zachwycony, że sądy czasami zwracają politykom i wyborcom [chciałoby się dodać „, innym sędziom” — F.R.] uwagę na istnienie ludzi, którym wiecznie wmawia się, że muszą czekać na osiągnięcie konsensusu — konsensusu wypracowywanego we wspólnocie politycznej, z której faktycznie są wykluczeni. [...] W przeciwieństwie do Dworkina Dewey

39 Zob. ibidem, s. 206-207.

40 Zob. ibidem, s. $351 \mathrm{n}$.

41 Zob. F. Rakoczy, Autonomia prawa a problem jego polityczności, [w:] Polityka/polityczność. Granice dyskursu, red. B. Krzysztan et al., Wrocław 2016, s. 223-224. 
nie próbowałby formułować ogólnej teorii prawa, uzasadniającej praktykę skoków w konstytucyjne nieznane. Moim zdaniem Dewey uznałby niespodziewane dostrzeganie istniejących już wcześniej, choć niewidocznych praw konstytucyjnych, za osobliwy sposób, w jaki nasze sądy dają wyraz przeświadczeniu o potrzebie wzburzenia politycznych wód ${ }^{42}$.

R. Rorty zdaje się zdejmować z ramion ustawodawcy część odpowiedzialności za wizję przyszłego świata i kształt współczesnej rzeczywistości na rzecz sędziów, których zadaniem jest nie tylko pilnowanie procedury przechodzenia od drugiego do pierwszego, ale także współkształtowanie przyszłego świata, przez adaptację zastanych przepisów prawa do zmieniającej się rzeczywistości społecznej. W ujęciu, które proponuję, prawnicy, w tym sędziowie, są nie tylko wykonawcami woli suwerena, tak jak chcieliby tego populiści. Zamiast realizować zamiar wyobrażonego, racjonalnego ustawodawcy, ich zadaniem wydaje się „robienie dobrej miny do złej gry”, a więc stosowanie prawa w najlepszy możliwy sposób, z zastrzeżeniem jednak granic tej praktyki. Jedną z tych granic jest treść aktu prawnego, drugą natomiast — kształt społeczeństwa, który, tak jak prawo, jest zawsze zastany dla każdego sędziego. Sędzia nie staje się w tym ujęciu reprezentantem społeczeństwa, tak jak oczekiwaliby tego populiści. Jest on raczej strażnikiem ram dyskursu prawnego, pilnującym w szczególności dostępu do prawa i jego rzeczywistej powszechności. Oczywiście wymiar sprawiedliwości nie dysponuje narzędziami socjologicznymi, pozwalającymi na dokładne badanie społeczeństwa i w zasadzie nie powinien się tym zajmować. Należy pamiętać, że jest on tylko jednym z elementów układanki, jaką jest demokracja — w związku z czym może w tym zakresie korzystać z narzędzi wykorzystywanych przez egzekutywę i legislatywę (na przykład sprawozdania z konsultacji społecznych projektu danej ustawy), a także z informacji dostarczanych przez samo społeczeństwo (na przykład protesty, manifestacje). Jako przykład takiego orzeczenia można wskazać fragment uzasadnienia zdania odrębnego sędziego O.W. Holmesa w sprawie Lochner vs. New York ${ }^{43}$ :

This case is decided upon an economic theory which a large part of the country does not entertain. If it were a question whether I agreed with that theory, I should desire to study it further and long before making up my mind. But I do not conceive that to be my duty, because I strongly believe that my agreement or disagreement has nothing to do with the right of a majority to embody their opinions in law.

\section{$[\ldots]$}

42 R. Rorty, Banalność pragmatyzmu i poezja sprawiedliwości, [w:] idem, Filozofia a nadzieja na lepsze społeczeństwo, przeł. J. Grygieńć, S. Tokariew, Toruń 2013, s. 153-154.

43 Orzeczenie dotyczyło sprawy z powództwa Lochnera przeciwko stanowi Nowy Jork, w której powód domagał się uznania stanowej regulacji, limitującej tydzień pracy do sześćdziesięciu godzin przez sześć dni w tygodniu, za niezgodną z Konstytucją USA. Jako wzorzec kontrolny wskazano zapisy Konstytucji USA, dotyczące swobody umów. W sprawie zapadło orzeczenie, uwzględniające powództwo, od którego zdanie odrębne złożył sędzia Holmes. 
Some of these laws embody convictions or prejudices which judges are likely to share. Some may not. But a constitution is not intended to embody a particular economic theory, whether of paternalism and the organic relation of the citizen to the State or of laissez faire. It is made for people of fundamentally differing views, and the accident of our finding certain opinions natural and familiar or novel and even shocking ought not to conclude our judgment upon the question whether statutes embodying them conflict with the Constitution of the United States. General propositions do not decide concrete cases. The decision will depend on a judgment or intuition more subtle than any articulate major premise ${ }^{44}$.

Po raz kolejny jednak należy zaznaczyć, że w tym ujęciu zadaniem sędziego nie jest odtwarzanie woli suwerena lub ustawodawcy, lecz jedynie stanie na straży stosowania prawa w taki sposób, który będzie gwarantował równy i powszechny dostęp do niego. W związku z tym analiza i krytyka orzeczeń wykorzystujących argumentację populistyczną nie tylko powinna polegać na odtworzeniu postulowanego świata możliwego, ale także na ustaleniu wizji społeczeństwa, jaka leży u podstaw takiego orzeczenia i sprawdzeniu, czy mieści się ona w ramach rzeczywistości społecznej. Wydaje się, że takie podejście, przyjęte przez prawników, w tym sędziów, pozwala nie tylko na rozpoznanie orzeczeń mających u swoich podstaw założenia populistyczne, ale także na skuteczną z nimi polemikę. Polemika ta mogłaby przybrać postać zarzutów apelacyjnych lub kasacyjnych, odnoszących się do błędnej wykładni prawa materialnego, połączonych z rekonstrukcją uzasadnienia i błędnych przesłanek, leżących u podstaw takiej interpretacji prawa. Ta polemika pozostaje jednak wyłącznie elementem dyskursu prawniczego, który z kolei jest jedynie wycinkiem naszej rzeczywistości politycznej. W związku z tym radzenie sobie ze zjawiskiem populizmu wymaga działań także na pozostałych płaszczyznach tej rzeczywistości.

\section{Podsumowanie}

Podsumowując powyższe, stwierdzić należy, że populizm jest także strategią argumentacyjną, możliwą do wykorzystania i wykorzystywaną w procesie stosowania prawa. Jako taki jest trudny do wychwycenia wyłącznie na gruncie kryteriów formalnych, albowiem właściwie ich nie narusza; mimo to materialnie jest naruszeniem zasady bezstronności sądu, ponieważ orzekający wyklucza określone grupy społeczne ze swojej wizji „narodu” lub „rdzennej krainy”. Pojęcia te najczęściej występują jako entymematy i aby do nich dotrzeć, konieczna jest rekonstrukcja argumentacji uzasadnienia orzeczenia. W tekście wskazałem jedynie kilka przykładów takiego rozumowania, możliwości w tym zakresie wydają się ograniczone jedynie wyobraźnią orzekającego. Niezależnie od tego orzeczenia te mają cechę wspólną, w postaci arbitralnie skonstruowanego pojęcia "lud" lub „suweren”, które zwykle jest elementem słownika finalnego orzekającego. W związku z tym konieczne jest przeprowadzenie symulacji mentalnej obrazują-

${ }^{44}$ https://supreme.justia.com/cases/federal/us/198/45/ (dostęp: 15.04.2020). 
cej desygnat tego pojęcia i sprawdzenie w ten sposób, czy faktycznie uwzględnia on obecną strukturę społeczną. Dla tego celu przedstawiłem istniejące w tym zakresie możliwości, jakie dają zmodyfikowane przeze mnie koncepcje M. Matczaka i R. Rorty’ego, umożliwiające diagnozę i walkę z tym problemem.

\section{Bibliografia}

Bottoms A., The philosophy and politics of punishment and sentencing, [w:] In the Politics of Sentencing Reforms, red. Ch. Clarkson, R. Morgan, Oxford 1995.

Brożek B., Umyst prawniczy, Kraków 2018.

Gromski W., Ideologia swobodnej decyzji stosowania prawa, [w:] Wprowadzenie do nauk prawnych. Leksykon tematyczny, red. A. Bator, Warszawa 2008.

Kaczmarek T., Racjonalny ustawodawca wobec opinii spolecznej a populizm penalny, [w:] Populizm penalny i jego przejawy w Polsce, red. Z. Sienkiewicz, R. Kokot, Wrocław 2009.

Kozak A., Granice prawniczej władzy dyskrecjonalnej, Wrocław 2002.

Leszczyński L., Stosowanie generalnych klauzul odsyłających, Kraków 2001.

Leszczyński L., Zagadnienia teorii stosowania prawa. Doktryna i tezy orzecznictwa, Kraków 2001.

Matczak M., Imperium tekstu. Prawo jako postulowanie i urzeczywistniania świata możliwego, Warszawa 2019.

Mouffe Ch., Polityczność. Przewodnik krytyki politycznej, Warszawa 2008.

Muller J.W., Co to jest populizm?, Warszawa 2017.

Penalny populizm. Perspektywa polityczna i społeczna, red. J. Czapska, M. Szafrańska, D. Wójcik, Kraków 2016.

Populizm penalny i jego przejawy w Polsce, red. Z. Sienkiewicz, R. Kokot, Wrocław 2009.

Prowotorow-Pryka A., Penalny populizm jako zespót społecznych przekonań, [w:] Penalny populizm. Perspektywa polityczna i społeczna, red. J. Czapska, M. Szafrańska, D. Wójcik, Kraków 2016.

Rakoczy F., Autonomia prawa a problem jego polityczności, [w:] Polityka/polityczność. Granice dyskursu, red. B. Krzysztan et al., Wrocław 2016.

Rorty R., Banalność pragmatyzmu i poezja sprawiedliwości, [w:] idem, Filozofia a nadzieja na lepsze społeczeństwo, przeł. J. Grygieńć, S. Tokariew, Toruń 2013.

Taggart P., Populizm, lud, rdzenna kraina, [w:] Populizm, red. O. Wysocka, Warszawa 2010.

Zalewski W., Populizm penalny — próba zdefiniowania zjawiska, [w:] Populizm penalny i jego przejawy w Polsce, red. Z. Sienkiewicz, R. Kokot, Wrocław 2009.

\section{Wykaz stron internetowych}

https://ipo.trybunal.gov.pl/ipo/view/sprawa.xhtml?\&pokaz=dokumenty\&sygnatura=K\%2016/17. https://ipo.trybunal.gov.pl/ipo/view/sprawa.xhtml? \&pokaz $=$ dokumenty\&sygnatura $=\mathrm{K} \% 20$ 16/17\#zdanieodrebne 18339 1.

https://supreme.justia.com/cases/federal/us/198/45.

Studenckie Prace Prawnicze, Administratywistyczne

i Ekonomiczne 31, 2020

(C) for this edition by CNS 